\title{
Antibacterial and anti-biofilm activity of the lipid extract from Mantidis ootheca on Pseudomonas aeruginosa
}

\author{
Wen-dong $\mathrm{WANG}^{\S 1}$, Nan-nan ZHANG ${ }^{\S 2}$, Warren CHANDA ${ }^{1}$, Min LIU $^{1}$, Syed Riaz ud DIN ${ }^{1}$, Yun-peng DIAO ${ }^{3}$, \\ Lei $\mathrm{LIU}^{1}$, Jing $\mathrm{CAO}^{1}$, Xiao-li WANG ${ }^{1}$, Xing-yun $\mathrm{LI}^{1}$, An-hong NING ${ }^{1}$, Min HUANG ${ }^{\dagger 1}$, Min-tao ZHONG ${ }^{\dagger 1}$ \\ ${ }^{1}$ Department of Medical Microbiology, Dalian Medical University, Dalian 116044, China \\ ${ }^{2}$ Department of Otolaryngology, Dalian Central Hospital, Dalian 116033, China \\ ${ }^{3}$ School of Pharmacy, Dalian Medical University, Dalian 116044, China \\ †E-mail: huangminchao@163.com; dyzhongmt@163.com
}

Received July 24, 2017; Revision accepted Sept. 6, 2017; Crosschecked Apr. 18, 2018

\begin{abstract}
The aim of this study is to assess the antibacterial and anti-biofilm properties of the lipid extract from Mantidis ootheca against the gentamycin resistant Pseudomonas aeruginosa. The chemical composition of the lipid extract and its relative proportion were determined using the technique of gas chromatography coupled with mass spectrometry (GC-MS). Antibacterial susceptibility tests were performed using a disc diffusion assay and the minimum inhibition concentration (MIC) was determined by way of the agar dilution method. The anti-biofilm test was carried out with crystal violet staining and scanning electron microscopy (SEM). There were 16 compounds detected, and the most abundant components were sesquiterpenoids, monoterpenes, and trace aromatic compounds. The MIC for $P$. aeruginosa was $4 \mathrm{mg} / \mathrm{ml}$ and the eradication effect on preformed biofilms was established and compared with a ciprofloxacin control. The results of our study indicated that a lipid extract from $M$. ootheca could be used as a topical and antibacterial agent with anti-biofilm activity in the future.
\end{abstract}

Key words: Antibacterial; Lipid extract; Mantidis ootheca; Pseudomonas aeruginosa https://doi.org/10.1631/jzus.B1700356

CLC number: R378.99

\section{Introduction}

Mantidis ootheca is the dry egg sheath of Tenodera sinensis Saussur, Statilia maculate, and $\mathrm{Hi}$ erodula patellifera, which belongs to the insects of the Mantis family (Wen et al., 2013). M. ootheca is one of the Chinese traditional medicinal insects, which is often used as a diuretic along with other Chinese medicines in the clinical treatment of renal failure, spermatorrhea, pediatric enuresis, and leukorrhea with reddish discharge (Tan et al., 1997).

\footnotetext{
ॠ Corresponding authors

$\S$ The two authors contributed equally to this work

(b) ORCID: Min-tao ZHONG, https://orcid.org/0000-0002-2190-1153

(C) Zhejiang University and Springer-Verlag GmbH Germany, part of Springer Nature 2018
}

Although M. ootheca is used traditionally to treat the above mentioned diseases, there is as yet no report on its effect in treating bacterial infections. The chemical components of the lipid extract from M. oothecal, its relative bioactivity, or its antibacterial and antibiofilm effects against Pseudomonas aeruginosa have not been reported.

$P$. aeruginosa is one of the most relevant microorganisms that causes human opportunistic infections. It can infect a wide range of ecological niches including animals and plants in both aquatic and soil habitats because of its special metabolic plasticity and versatility (Silby et al., 2011; Gellatly and Hancock, 2013). P. aeruginosa is capable of causing acute nosocomial infections, and it particularly affects immunocompromised patients and patients in 
the intensive care unit (ICU). It is the most relevant pathogen causing ventilator-associated pneumonia and burn wound infections, which are related to a very high mortality rate ( $>30 \%$ ) (Oliver et al., 2015). Additionally, $P$. aeruginosa is a common cause of chronic respiratory infections in patients suffering from cystic fibrosis (CF), chronic obstructive pulmonary disease (COPD), and bronchiectasis (Oliver et al., 2015).

The usage of antibiotics has treated many devastating bacterial infections in humans. However, in recent years, the abuse of antibiotics has led to an increase in the emergence of multidrug resistant (MDR) bacteria, which makes it vital to look for novel effective drugs (O'Donnell et al., 2010). With the emerging resistance, researchers have gradually realized that the unique effects of natural products can provide abundant materials in which to find new antibacterial drugs for fighting MDR bacteria. The formation of biofilm protects the bacteria, which contributes significantly to several medical challenges such as symptomatic inflammation, antibiotic resistance, the recurrence and spread of infectious emboli, and also enables the bacteria to survive in severe conditions such as high temperatures and high concentrations of antibiotic treatments, all of which make it more challenging to treat biofilm-associated infection (BAI) (Costerton et al., 1999; Kim et al., 2012). BAI includes the infections on indwelling medical devices such as intravascular catheters, cardiac devices, and prosthetic joints, and it can also develop on indwelling medical devices independently such as in native valve endocarditis, open wounds, and dental plaque (Joo and Otto, 2012). Microbial biofilms pose global economic challenges in connection with equipment damage, product contamination, energy losses, and infections (Yang et al., 2012). In the USA, approximately 17 million people suffer from chronic infections each year and nearly 3\% of these die as a result (Wolcott et al., 2010). Novel drugs that can treat both the planktonic bacteria and bacterial biofilm are therefore required.

This article focuses on the chemical composition, antibacterial activity, and anti-biofilm activity of the lipid extract from M. ootheca. The efficacy of the lipid extract was evaluated and compared with ciprofloxacin as a positive control against a $P$. aeruginosa strain that is resistant to gentamicin.

\section{Materials and methods}

\subsection{Lipid extract preparation}

Following the method of Li et al. (2009) with some modifications, $M$. ootheca was ground into a powder and $10 \mathrm{~g}$ of the dry powder was taken into a Soxhlet extractor. A volume of $220 \mathrm{ml}$ of chloroform/ methanol $(2: 1, \mathrm{v} / \mathrm{v})$ was then added to the powder and heated at $60{ }^{\circ} \mathrm{C}$ in water for $2 \mathrm{~h}$, before cooling the extracted liquid to room temperature, adding $30 \mathrm{~g}$ anhydrous sodium sulfate for $10 \mathrm{~min}$, and then evaporating it to dryness at $40{ }^{\circ} \mathrm{C}$ by rotatory evaporator. The liquid was transferred into a separating funnel and extracted using diethyl ether. Finally, the lipid extract was obtained after drying the extracted liquid with a vacuum pump in a $40^{\circ} \mathrm{C}$ water bath for $30 \mathrm{~min}$, and was stored at $4{ }^{\circ} \mathrm{C}$ in amber glass vials before analysis.

\subsection{Analytical conditions of the gas chromatog- raphy coupled with mass spectrometry (GC-MS)}

According to the method developed by Sitaram et al. (2011) with some modifications, the gas chromatography conditions included the chromatography column DB1701 $(30 \mathrm{~m} \times 320 \mu \mathrm{m} \times 0.25 \mu \mathrm{m})$ elastic quartz capillary column. Temperature programming involved keeping the initial temperature at $50{ }^{\circ} \mathrm{C}$ for $3 \mathrm{~min}$, then raising it to $280^{\circ} \mathrm{C}$ for $20 \mathrm{~min}$ at a rate of $10{ }^{\circ} \mathrm{C} / \mathrm{min}$. The temperature at the sample-feeding gate was $280^{\circ} \mathrm{C}$ and the split sampling ratio was $50: 1$ $(\mathrm{v} / \mathrm{v})$. The mass spectrometry conditions were as follows: the electron bombard was the electron impact (EI) ionization source, the ionizing energy was $70 \mathrm{eV}$, the temperature of the ionization source was $200{ }^{\circ} \mathrm{C}$ and the temperature of the connector was $250{ }^{\circ} \mathrm{C}$. The mass spectra library used by the US National Institute of Standards and Technology (NIST, Gaithersburg, Maryland, USA) was used and the relative content of each component was calculated by their normalized peak area.

\subsection{Bacterial strain and growth condition}

The studied strain $P$. aeruginosa was isolated from patients suffering from CF in the Second Affiliated Hospital of Dalian Medical University (Dalian, China). The strain was determined by the TaKaRa company (Dalian, China) by the 16S rDNA amplification method, and the results were compared with 
data from the National Center for Biotechnology Information (NCBI). The sequences producing significant alignments were $100 \%$ identical and it was confirmed that the tested strain was a $P$. aeruginosa strain. Stock cultures of bacteria were prepared and stored with $8 \%$ glycerol at $-80{ }^{\circ} \mathrm{C}$. The strain was sub-cultured on Luria-Bertani (LB) broth agar plates containing tryptone $(10 \mathrm{~g} / \mathrm{L})$, yeast extract $(5 \mathrm{~g} / \mathrm{L})$, $\mathrm{NaCl}(10 \mathrm{~g} / \mathrm{L}), 1 \mathrm{~mol} / \mathrm{L} \mathrm{NaOH}(0.2 \%$, v/v), and agar $(20 \mathrm{~g} / \mathrm{L})$ dissolved in $500 \mathrm{ml}$ of tri-distilled water and stored in the fridge at $4{ }^{\circ} \mathrm{C}$ before any antibacterial testing. Single colonies were frequently replanted every 4 weeks. All broth and glassware, which were used for bacterial growth, were autoclaved at $121{ }^{\circ} \mathrm{C}$ for $30 \mathrm{~min}$ by high pressure steam sterilizer.

\subsection{Disc diffusion assay}

The antibacterial activity of the lipid extract from $M$. ootheca was initially analyzed using a disc diffusion assay according to the M2-A8 method as described by the Clinical Laboratory and Standards Institute (CLSI). Müeller-Hinton agar $(0.042 \mathrm{~g} / \mathrm{ml})$ was dissolved in $200 \mathrm{ml}$ of tri-distilled water and autoclaved at $121^{\circ} \mathrm{C}$ for $30 \mathrm{~min}$, cooled to $55^{\circ} \mathrm{C}$, and then poured onto glass plates and cooled to room temperature. The plates were stored in the fridge at $4{ }^{\circ} \mathrm{C}$. One colony of the tested strain was transferred to LB broth and cultured at $37^{\circ} \mathrm{C}$, and the overnight culture was suspended in LB broth to a cell suspension of 0.5 McFarland turbidity prior to inoculation on the Müeller-Hinton agar plates. The discs $(6 \mathrm{~mm}$ in diameter) were impregnated with $15 \mu \mathrm{l}$ of the lipid extract ( $3 \mathrm{mg} / \mathrm{disc}$ ) dissolved in dimethyl sulfoxide (DMSO) to a final concentration of $200 \mathrm{mg} / \mathrm{ml}$ and placed on Müeller-Hinton agar plates containing bacterial inoculum. Discs impregnated with $15 \mu \mathrm{l}$ DMSO were used as a control, while discs with $10 \mu \mathrm{g}$ gentamycin or $5 \mu \mathrm{g}$ ciprofloxacin were included according to CLSI. The diameters (mm) of the inhibition zones were measured after overnight incubation at $37^{\circ} \mathrm{C}$. The experiment was carried out in triplicate.

\subsection{Determination of minimum inhibition con- centration (MIC)}

The agar dilution method was performed according to the M7-A6 protocol published by CLSI to determine the minimum inhibition concentration (MIC) of the lipid extract from $M$. ootheca against the bacteria strain tested. The Müeller-Hinton agar base $(0.042 \mathrm{~g} / \mathrm{ml})$ was dissolved in $100 \mathrm{ml}$ of tri-distilled water and autoclaved at $121{ }^{\circ} \mathrm{C}$ for $30 \mathrm{~min}$ before cooling to $55^{\circ} \mathrm{C}$. The lipid extract was then poured in and blended, and was poured onto plastic plates and cooled to room temperature. Plates with serial concentrations of the lipid extract were prepared. One colony of the tested strain was transferred to the LB broth and cultured at $37^{\circ} \mathrm{C}$, the overnight culture was measured and adjusted to $0.5 \mathrm{McFarland}$ turbidity by diluting with LB broth. The assay was conducted by putting $2 \mu \mathrm{l}$ of the bacterial cell suspension per spot onto the plates. The final quantity of bacteria was $1 \times 10^{5}$ CFU (colony-forming unit) per spot. The Müeller-Hinton agar without the lipid extract was used as the control, and a medium with DMSO was also prepared. The plates were incubated for $20 \mathrm{~h}$ at $37{ }^{\circ} \mathrm{C}$. Each lipid extract concentration was tested against the strain three times. MIC was defined as the lowest concentration of the lipid extract that inhibited the growth of the bacteria by visual inspection.

The MIC determination of ciprofloxacin for the strain was performed by the broth dilution method according to the method by de Zoysa et al. (2015) with some modifications. In general, ciprofloxacin was dissolved in sterile water and a series of dilutions were made. The assay was conducted by putting $4 \mu \mathrm{l}$ of each of the ciprofloxacin solutions at several concentrations and $96 \mu \mathrm{l}$ of the bacterial culture into a 96-well culture plate. Each concentration was repeated five times. The lowest concentration that showed no bacterial growth after $24 \mathrm{~h}$ of incubation was defined as MIC, which was determined by both visual inspection and absorbance at $600 \mathrm{~nm}$.

\subsection{Effect of the lipid extract on preformed biofilms}

The experiment for biofilm eradication was conducted according to the method described by de Zoysa et al. (2015) with some modifications. The ability of the lipid extract from $M$. ootheca to eradicate preformed biofilms of the strain was evaluated by crystal violet staining in 12-well plates. Preformed biofilms of the strain were prepared in 12-well plates. A bacterial cell suspension $(1 \mathrm{ml})$ corresponding to $1 \times 10^{8} \mathrm{CFU} / \mathrm{ml}$ and $1 \mathrm{ml}$ of LB broth was prepared in the plates. The final inoculum was $6 \times 10^{7} \mathrm{CFU} / \mathrm{ml}$ in each well. The plates were incubated at $37{ }^{\circ} \mathrm{C}$ for $24 \mathrm{~h}$. After incubation, the supernatant was removed 
carefully without injuring the preformed biofilm architecture and gently washed twice with $2 \mathrm{ml}$ of phosphate-buffered saline (PBS). Thereafter, $2 \mathrm{ml}$ of LB broth with DMSO (negative control), $2 \mathrm{ml}$ of the MIC of the lipid extract in sterile LB broth, and $2 \mathrm{ml}$ of the MIC of ciprofloxacin in sterile LB broth (positive control) were added and incubated for a further $24 \mathrm{~h}$ at $37^{\circ} \mathrm{C}$. The supernatant was removed from each well after the second incubation and the wells were gently washed twice with PBS and stained with $1 \mathrm{ml}$ of $0.1 \%$ crystal violet for $10 \mathrm{~min}$. After staining, the crystal violet was removed and the wells were washed thrice with $1 \mathrm{ml}$ of sterile water. The marked biofilms of each well were observed at $40 \times$ magnification under microscope. The procedure was done in triplicate.

\subsection{Scanning electron microscopy}

For the scanning electron microscopy (SEM) analysis, 12-well plates including plastic coverslips were prepared. After preparing the same double $24 \mathrm{~h}$ bacteria culture as described above, the plastic coverslips were washed with PBS buffer to remove the extra bacteria. Then each plastic coverslip was fixed in $2.5 \%$ glutaraldehyde for $30 \mathrm{~min}$, then in $1 \%$ osmium tetraoxide for another $30 \mathrm{~min}$. The samples were then dehydrated in a series of ethanol solutions which increased from $50 \%$ to $100 \%$ sequentially. Finally, samples were critical-point dried, then coated with $15 \mathrm{~nm}$ of gold, and examined by SEM (Murphy et al., 2014).

\section{Results}

\subsection{Analytical results of the GC-MS}

The lipid extract from $M$. ootheca was in the form of an oily liquid that had a faint yellow color and a rich fragrance. This lipid was extracted from $M$. ootheca by vapor distillation, with a fatty acid yield of $2.72 \%$. Its chemical composition was quantified by GC-MS: the total ion flow chart of the lipid extract is shown in Fig. 1 and the identification and content of chemical components in the lipid extract are presented in Table 1.

A total of 16 compounds were determined to be present in the extract, which accounted for $96.8 \%$ of the total peak area of the appraised components. The
Table 1 Analytical results of chemical constituents of the lipid extract from Mantidis ootheca by GC-MS

\begin{tabular}{lccc}
\hline \multicolumn{1}{c}{ Component } & $\begin{array}{c}\text { RT } \\
\text { (min) }\end{array}$ & $\begin{array}{c}\text { Molecular } \\
\text { formula }\end{array}$ & $\begin{array}{c}\text { Relative } \\
\text { content (\%) }\end{array}$ \\
\hline Ethyl-9-hexadecenoate & 22.701 & $\mathrm{C}_{18} \mathrm{H}_{34} \mathrm{O}_{2}$ & 0.69 \\
Hexadecanoic acid ethyl & 22.772 & $\mathrm{C}_{18} \mathrm{H}_{36} \mathrm{O}_{2}$ & 0.44 \\
ester & & & \\
Z-11-Hexadecenoic acid & 23.437 & $\mathrm{C}_{16} \mathrm{H}_{30} \mathrm{O}_{2}$ & 2.07 \\
n-Hexadecanoic acid & 23.457 & $\mathrm{C}_{16} \mathrm{H}_{32} \mathrm{O}_{2}$ & 3.32 \\
Z-9-Octadecenoic acid & 23.880 & $\mathrm{C}_{19} \mathrm{H}_{36} \mathrm{O}_{2}$ & 0.24 \\
methyl ester & & & \\
Z,Z-9,12-Octadecadienoic & 24.082 & $\mathrm{C}_{18} \mathrm{H}_{32} \mathrm{O}_{2}$ & 0.04 \\
acid & & & \\
Ethyl oleate & 24.427 & $\mathrm{C}_{20} \mathrm{H}_{38} \mathrm{O}_{2}$ & 6.01 \\
9,12-Octadecadienoic acid & 24.476 & $\mathrm{C}_{20} \mathrm{H}_{36} \mathrm{O}_{2}$ & 2.37 \\
ethyl ester & & & \\
9,12,15-Octadecatrienoic & 24.621 & $\mathrm{C}_{20} \mathrm{H}_{34} \mathrm{O}_{2}$ & 1.81 \\
acid ethyl ester & & & \\
Oleic acid & 25.201 & $\mathrm{C}_{18} \mathrm{H}_{34} \mathrm{O}_{2}$ & 51.22 \\
9,12-Octadecadienoic acid & 25.241 & $\mathrm{C}_{18} \mathrm{H}_{32} \mathrm{O}_{2}$ & 14.26 \\
9,12,15-Octadecatrienoic & 25.368 & $\mathrm{C}_{18} \mathrm{H}_{30} \mathrm{O}_{2}$ & 14.26 \\
acid & & & \\
Heptacosane & 28.124 & $\mathrm{C}_{27} \mathrm{H}_{56}$ & 0.27 \\
Octacosane & 30.361 & $\mathrm{C}_{28} \mathrm{H}_{58}$ & 1.48 \\
Hentriacontane & 33.656 & $\mathrm{C}_{31} \mathrm{H}_{64}$ & 0.52 \\
Tetratetracontane & 35.245 & $\mathrm{C}_{44} \mathrm{H}_{90}$ & 0.49 \\
\hline RT: retention time & & &
\end{tabular}

most abundant components detected in the extract were sesquiterpenoids and monoterpene in addition to the small-molecule aromatic components. The contents of the components in the lipid extract were found to be mainly: compound 1, oleic acid $(51.22 \%)$; compound 2, 9,12-octadecadienoi acid (14.26\%); compound 3, 9,12,15-octadecatrienoic acid (14.26\%); compound 4, ethyl oleate (6.01\%); compound 5, $n$-hexadecanoic acid ethyl ester (3.32\%); compound 6, 9,12-octadecadienoic acid ethyl ester $(2.37 \%)$; compound 7, Z-11-hexadecenoic acid (2.07\%); compound 8, 9,12,15-octadecatrienoic acid ethyl ester (1.81\%); compound 9 , octacosane $(1.48 \%)$. Their structures are presented in Fig. 2.

\subsection{Antibacterial assay}

The ability of the lipid extract from $M$. ootheca to eradicate preformed biofilms of the strain tested was examined by the crystal violet staining method, and compared with ciprofloxacin. Microscopic images of biofilms, which were stained with crystal violet after $24 \mathrm{~h}$ of treatment with the MIC of the 


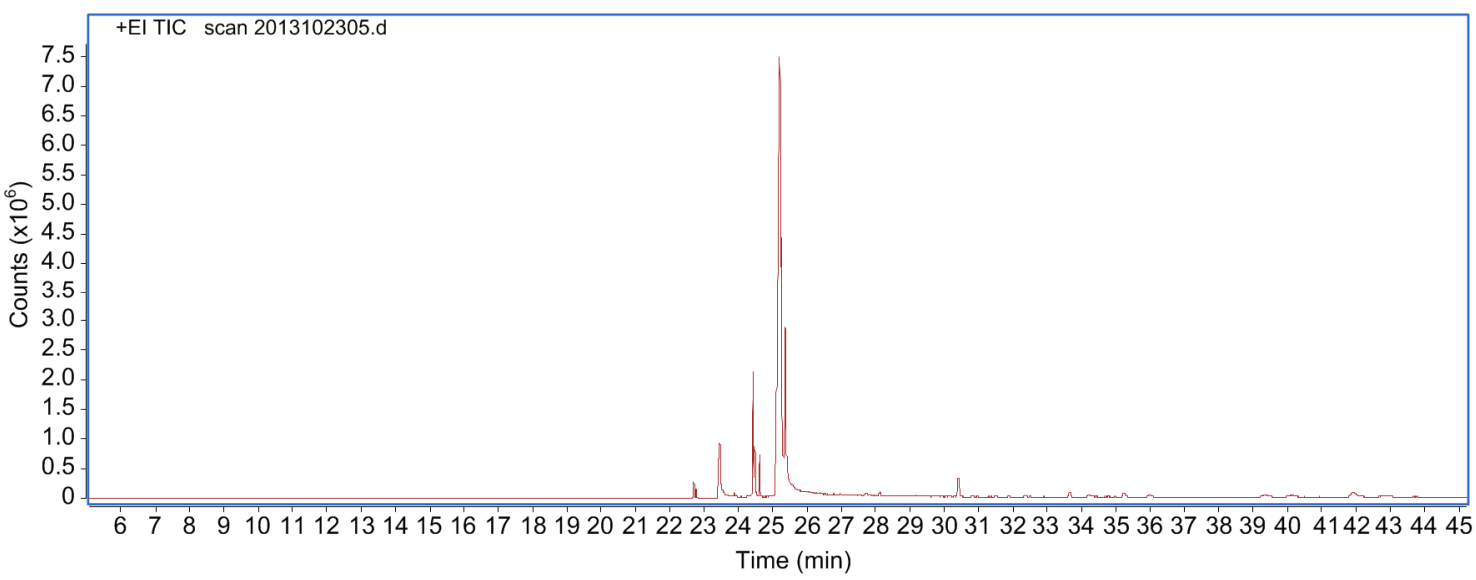

Fig. 1 GC-MS total ion current chromatogram of the lipid extract from Mantidis ootheca

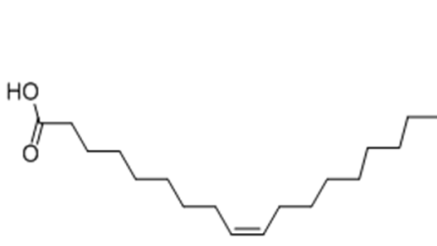<smiles>CCCCCCCC/C=C\CCCCCCCC(=O)OCC</smiles>

Compound 4

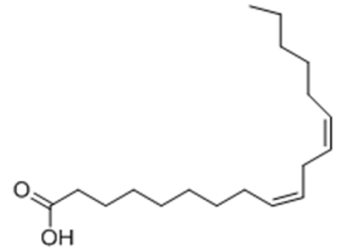

Compound 2

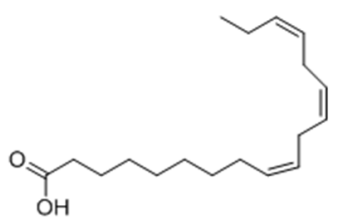

Compound 3

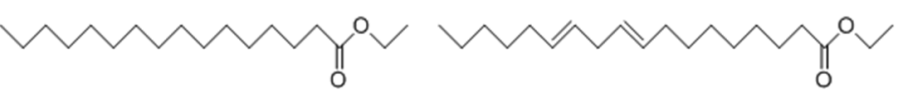

Compound 5

Compound 6

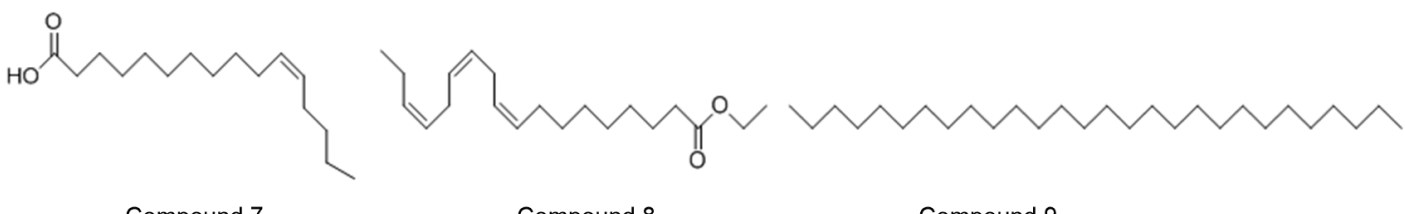

Compound 7

Compound 8

Compound 9

Fig. 2 Representative compounds of the lipid extract from Mantidis ootheca

lipid extract on preformed biofilms (Fig. 3) clearly showed the disruption of the biofilm structure and the decrease of the adhesive bacteria.

\subsection{SEM}

The effect of the lipid extract from $M$. ootheca on the morphology of the tested bacteria was studied using SEM (Fig. 4). Untreated bacterial cells were rod-shaped, with all cells presenting smooth intact surfaces. Treatment with the lipid extract at MIC and with the positive control led to severely disordered cell membranes, resulting in a corrugated and blistered appearance. Bacterial lysis was also detected with cellular remnants scattered across.

\section{Discussion}

$P$. aeruginosa is the main bacterium related to nosocomial infections, and has become more and more difficult to treat due to multiple drug resistance. It is also an opportunistic pathogen which can form biofilms and colonizes in the lung tissues of CF patients without good treatment (Lam et al., 1980). 


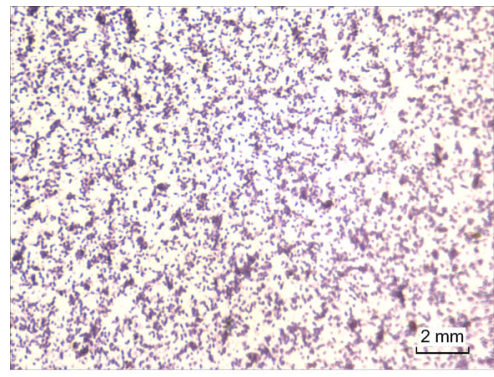

(a)

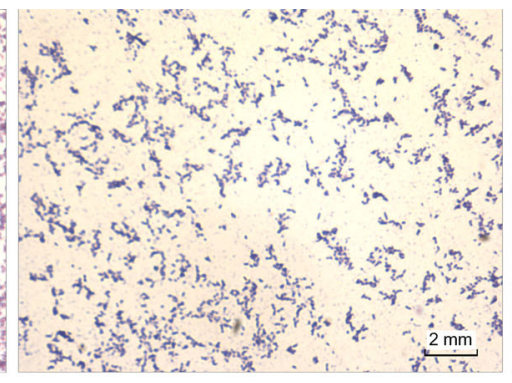

(b)

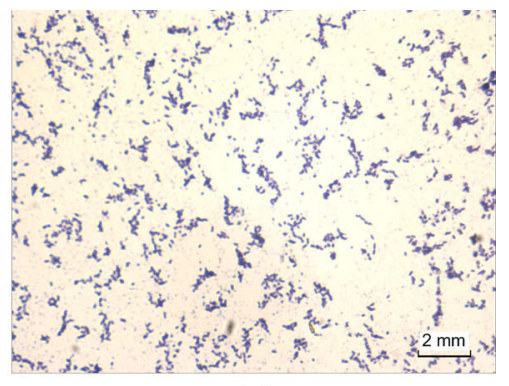

(c)

Fig. 3 Effect of treating preformed biofilms with the lipid extract from Mantidis ootheca at MIC for $24 \mathrm{~h}$, imagined by microscopy with crystal violet staining

(a) DMSO control; (b) Lipid extract group; (c) Ciprofloxacin at $5 \mu \mathrm{g} / \mathrm{ml}$

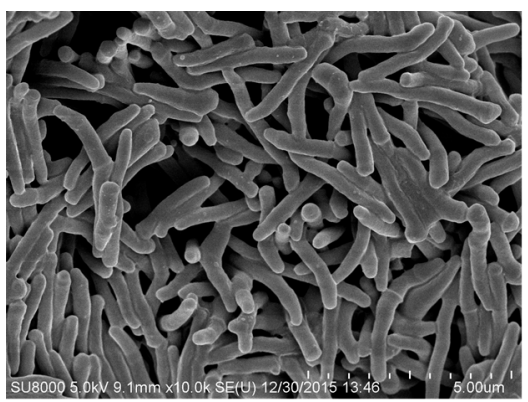

(a)

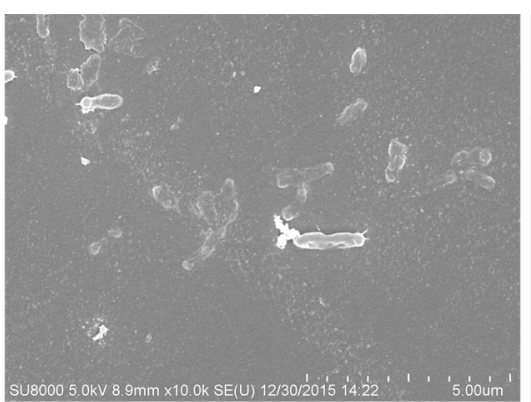

(b)

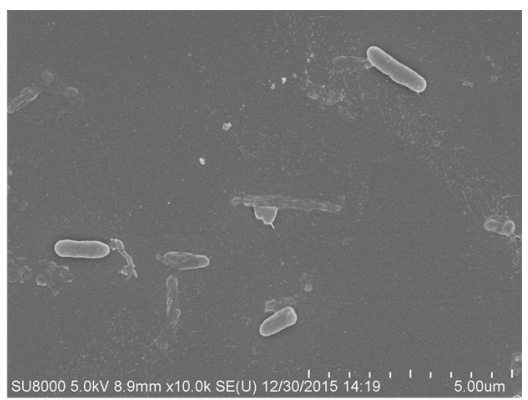

(c)

Fig. 4 SEM images of the Pseudomonas aeruginosa

(a) DMSO control; (b) Lipid extract group; (c) Ciprofloxacin at $5 \mu \mathrm{g} / \mathrm{ml}$

Antibiotic resistance is a threat to human and animal health worldwide, and current antibacterial drugs cannot solve the problem with satisfaction (Berendonk et al., 2015). The formation of biofilm can provide the bacteria with a shield of a hydrated substance including polysaccharides and proteins (Sutherland, 2001), which makes treatment more difficult by increasing antibiotic resistance in bacteria. It has been demonstrated that about $80 \%$ of bacterial infections are related to biofilms, which offer bacteria protection and make treatment more difficult (Davies, 2003). It will be ideal to produce antibacterial drugs which can not only inhibit bacterial growth but also eradicate preformed biofilm to treat BAI in the future. The disadvantages of existing antibiotics and the demand for novel effective materials that have both antibacterial and anti-biofilm properties indicated that antibacterial drugs with a new mechanism of action should be urgently industrialized (Stewart and Costerton, 2001; Orhan et al., 2010).

So many new drugs originate from natural products dating back to ancient times because of their unique structural diversities (Baker et al., 2007). Studies on natural products for treating refractory infections have amassed significantly, resulting in the exploration of compounds with anti-biofilm ability (Chung and Toh, 2014). Previous data on natural products indicated vast potentials in treating BAI (Wang et al., 2015). For example, four compounds isolated from Krameria, Aesculus hippocastanum, and Chelidonium majus exhibited inhibition of biofilm formation in Staphylococcus aureus and Staphylococcus epidermidis strains; another two compounds that have displayed capacity for new drug manufacture (Artini et al., 2012). Tea tree oil, which was isolated from the leaves of Melaleuca alternifolia or tea tree, showed activity in eradicating the biofilms of $S$. aureus, including meticillin-resistant $S$. aureus (MRSA), by destroying the extracellular matrix and then removing the biofilm from the surface (Kwiecinski et al., 2009). Papa et al. (2015) found that some bioactive compounds, which derived from marine cold-adapted bacteria, showed anti-biofilm activity on Staphylococci and P. aeruginosa. In another research (Luis et al., 2014), Hakea sericea Schrader extracts displayed an obvious effect by inhibiting the biofilm formation of $S$. aureus including MRSA. The study of artemisinin (qinghaosu) by 2015 Nobel Prize 
winner $\mathrm{Tu}(2011)$ indicated the enormous potential of Chinese natural products.

In this study, the antibacterial and anti-biofilm properties of the lipid extract of $M$. ootheca against $P$. aeruginosa were evaluated and compared with ciprofloxacin. The lipid extract from $M$. ootheca consists of more than 16 compounds, and the proportions of oleic acid, 9,12-octadecadienoic acid, and 9,12,15-octadecatrienoic acid collectively comprise up to $79.74 \%$ of the extract. Some extracts from other natural products containing oleic acid, 9,12octadecadienoic acid, or 9,12,15-octadecatrienoic acid were demonstrated to have antibacterial properties in previous studies (Clementi et al., 2013; Musa et al., 2015; Patra et al., 2015). However, whether the antibacterial function results from a single component or the synergistic action of several components has not yet been studied in detail. The purification and analysis of each compound need further investigation to understand the antibacterial and anti-biofilm properties. The MIC for the tested strain was $4 \mathrm{mg} / \mathrm{ml}$. However, a standard MIC measurement was designed for planktonic bacteria which did not reveal the real antibiotic susceptibility of biofilms (Costerton et al., 1995). Therefore, an anti-biofilm assay was performed to evaluate the effect of the lipid extract on biofilm eradication. With the crystal violet staining, the lipid extract showed an obvious effect on the eradication of preformed biofilm compared with ciprofloxacin.

In the SEM assay, the results clearly indicated that the lipid extract caused severe damage to the cell membrane of the attached bacterial cells, and showed an obvious effect on biofilm, compared with the untreated bacteria. The lipid extract from M. ootheca, which was previously not reported to be related to antibacterial activities, showed an obvious effect not only on planktonic bacteria, but also on bacteria in biofilms. The results of the study indicated that the lipid extract from $M$. ootheca could be used as a topical and antibacterial agent with anti-biofilm activity in the future. However, further research is needed to determine the specific compound in $M$. ootheca that creates the observed effect.

\section{Acknowledgements}

We sincerely thank Prof. Jing WANG (Dalian University, Dalian, China) for providing technical assistance for this study.

\section{Compliance with ethics guidelines}

Wen-dong WANG, Nan-nan ZHANG, Warren CHANDA, Min LIU, Syed Riaz ud DIN, Yun-peng DIAO, Lei LIU, Jing CAO, Xiao-li WANG, Xing-yun LI, An-hong NING, Min HUANG, and Min-tao ZHONG declare that they have no conflict of interest.

This article does not contain any studies with human or animal subjects performed by any of the authors.

\section{References}

Artini M, Papa R, Barbato G, et al., 2012. Bacterial biofilm formation inhibitory activity revealed for plant derived natural compounds. Bioorg Med Chem, 20(2):920-926. https://doi.org/10.1016/j.bmc.2011.11.052

Baker DD, Chu M, Oza U, et al., 2007. The value of natural products to future pharmaceutical discovery. Nat Prod Rep, 24(6):1225-1244. https://doi.org/10.1039/b602241n

Berendonk TU, Manaia CM, Merlin C, et al., 2015. Tackling antibiotic resistance: the environmental framework. Nat Rev Microbiol, 13(5):310-317. https://doi.org/10.1038/nrmicro3439

Chung PY, Toh YS, 2014. Anti-biofilm agents: recent breakthrough against multi-drug resistant Staphylococcus aureus. Pathog Dis, 70(3):231-239. https://doi.org/10.1111/2049-632X.12141

Clementi EA, Wilhelm KR, Schleucher J, et al., 2013. A complex of equine lysozyme and oleic acid with bactericidal activity against Streptococcus pneumoniae. PLoS ONE, 8(11):e80649. https://doi.org/10.1371/journal.pone.0080649

Costerton JW, Lewandowski Z, Caldwell DE, et al., 1995. Microbial biofilms. Ann Rev Microbiol, 49:711-745. https://doi.org/10.1146/annurev.mi.49.100195.003431

Costerton JW, Stewart PS, Greenberg EP, 1999. Bacterial biofilms: a common cause of persistent infections. Science, 284(5418):1318-1322.

Davies D, 2003. Understanding biofilm resistance to antibacterial agents. Nat Rev Drug Discov, 2(2):114-122. https://doi.org/10.1038/nrd1008

de Zoysa GH, Cameron AJ, Hegde VV, et al., 2015. Antimicrobial peptides with potential for biofilm eradication: synthesis and structure activity relationship studies of battacin peptides. J Med Chem, 58(2):625-639. https://doi.org/10.1021/jm501084q

Gellatly SL, Hancock RE, 2013. Pseudomonas aeruginosa: new insights into pathogenesis and host defenses. Pathog Dis, 67(3):159-173. https://doi.org/10.1111/2049-632X.12033

Joo HS, Otto M, 2012. Molecular basis of in vivo biofilm formation by bacterial pathogens. Chem Biol, 19(12): 1503-1513. https://doi.org/10.1016/j.chembiol.2012.10.022

Kim J, Park HD, Chung S, 2012. Microfluidic approaches to bacterial biofilm formation. Molecules, 17(8):9818-9834. https://doi.org/10.3390/molecules 17089818 
Kwiecinski J, Eick S, Wojcik K, 2009. Effects of tea tree (Melaleuca alternifolia) oil on Staphylococcus aureus in biofilms and stationary growth phase. Int $J$ Antimicrob Agents, 33(4):343-347. https://doi.org/10.1016/j.ijantimicag.2008.08.028

Lam J, Chan R, Lam K, et al., 1980. Production of mucoid microcolonies by Pseudomonas aeruginosa within infected lungs in cystic fibrosis. Infect Immun, 28(2):546556.

Li J, Wu HQ, Liu ZG, 2009. Acaricidal activity of clove bud oil against Dermatophagoides farinae (Acari: Pyroglyphidae). Chin J Parasitol Parasit Dis, 27(6):492-493, 497 (in Chinese).

Luis A, Breitenfeld L, Ferreira S, et al., 2014. Antimicrobial, antibiofilm and cytotoxic activities of Hakea sericea Schrader extracts. Pharmacogn Mag, 10(Suppl 1):S6-S13. https://doi.org/10.4103/0973-1296.127331

Murphy K, Park AJ, Hao Y, et al., 2014. Influence of O polysaccharides on biofilm development and outer membrane vesicle biogenesis in Pseudomonas aeruginosa PAO1. J Bacteriol, 196(7):1306-1317. https://doi.org/10.1128/JB.01463-13

Musa AM, Ibrahim MA, Aliyu AB, et al., 2015. Chemical composition and antimicrobial activity of hexane leaf extract of Anisopus mannii (Asclepiadaceae). J Intercult Ethnopharmacol, 4(2):129-133. https://doi.org/10.5455/jice.20150106124652

O'Donnell F, Smyth TJP, Ramachandran VN, et al., 2010. A study of the antimicrobial activity of selected synthetic and naturally occurring quinolones. Int $J$ Antimicrob Agents, 35(1):30-38. https://doi.org/10.1016/j.ijantimicag.2009.06.031

Oliver A, Mulet X, Lopez-Causape C, et al., 2015. The increasing threat of Pseudomonas aeruginosa high-risk clones. Drug Resist Updat, 21-22:41-59. https://doi.org/10.1016/j.drup.2015.08.002

Orhan DD, Ozcelik B, Ozgen S, et al., 2010. Antibacterial, antifungal, and antiviral activities of some flavonoids. Microbiol Res, 165(6):496-504. https://doi.org/10.1016/j.micres.2009.09.002

Papa R, Selan L, Parrilli E, et al., 2015. Anti-biofilm activities from marine cold adapted bacteria against staphylococci and Pseudomonas aeruginosa. Front Microbiol, 6:1333. https://doi.org/10.3389/fmicb.2015.01333

Patra JK, Das G, Baek KH, 2015. Chemical composition and antioxidant and antibacterial activities of an essential oil extracted from an edible seaweed, Laminaria japonica L. Molecules, 20(7):12093-12113. https://doi.org/10.3390/molecules200712093

Silby MW, Winstanley C, Godfrey SA, et al., 2011. Pseudomonas genomes: diverse and adaptable. FEMS Microbiol Rev, 35(4):652-680. https://doi.org/10.1111/j.1574-6976.2011.00269.x

Sitaram C, Rupakula RB, Reddy BN, et al., 2011. Determination of alkyl methanesulfonates in doxazosin mesylate by gas chromatography-mass spectrometer. Indian J Pharm
Sci, 73(1):107-110.

https://doi.org/10.4103/0250-474X.89769

Stewart PS, Costerton JW, 2001. Antibiotic resistance of bacteria in biofilms. Lancet, 358(9276):135-138. https://doi.org/10.1016/S0140-6736(01)05321-1

Sutherland IW, 2001. The biofilm matrix — an immobilized but dynamic microbial environment. Trends Microbiol, 9(5): 222-227. https://doi.org/10.1016/S0966-842X(01)02012-1

Tan Z, Lei Y, Zhang B, et al., 1997. Comparison of pharmacological studies on Ootheca Mantidis. China J Chin Mater Med, 22(8):496-499 (in Chinese).

$\mathrm{Tu}$ YY, 2011. The discovery of artemisinin (qinghaosu) and gifts from Chinese medicine. Nat Med, 17(10):1217-1220. https://doi.org/10.1038/nm.2471

Wang W, Chanda W, Zhong M, 2015. The relationship between biofilm and outer membrane vesicles: a novel therapy overview. FEMS Microbiol Lett, 362(15):fnv117. https://doi.org/10.1093/femsle/fnv117

Wen LL, Wan DG, Ren Y, et al., 2013. Corresponding relationship between Mantis and Mantidis oötheca (Sangpiaoxiao). China J Chin Mater Med, 38(7):966-968 (in Chinese).

Wolcott RD, Rhoads DD, Bennett ME, et al., 2010. Chronic wounds and the medical biofilm paradigm. $J$ Wound Care, 19(2):45-46.

https://doi.org/10.12968/jowc.2010.19.2.46966

Yang L, Liu Y, Wu H, et al., 2012. Combating biofilms. FEMS Immunol Med Microbiol, 65(2):146-157. https://doi.org/10.1111/j.1574-695X.2011.00858.x

\section{中文概要}

题 目: 桑螵蛸脂类提取物对铜绿假单胞菌的抗菌活性和 抗生物膜作用

目 的: 探究桑螵蛸脂类提取物的成分及对铜绿假单胞菌 的抗菌和抗生物膜作用。

创新点: 中国传统中药桑螵蛸一直广泛应用于肾病的治 疗, 在抗菌领域未见报道, 本实验首次证明桑螵 蛸脂类提取物对铜绿假单胞菌有明显的抗菌和 抗生物膜作用。

方 法: 采用气相色谱一质谱联用技术, 测定桑螵蛸脂质 提取物的化学成分及其相对比例。采用纸片扩散 法和琼脂平板稀释法观察桑螵蛸脂类提取物对 铜绿假单胞菌的抑菌效应并测定最小抑制浓度 (MIC)。采用结晶紫染色法和扫描电镜 (SEM) 进行抑制生物被膜的试验。

结 论: 桑螵蛸脂类提取物中含有 16 种化合物, 最丰富 的成分分别是倍半萜类化合物、单萜和微量芳香 族化合物。桑螵蛸脂类提取物对铜绿假单胞菌的 $\mathrm{MIC}$ 为 $4 \mathrm{mg} / \mathrm{ml}$, 对铜绿假单胞菌生物被膜的抑 制作用明显。

关键词: 抗菌药; 脂类提取物; 桑螵蛸; 铜绿假单胞菌 